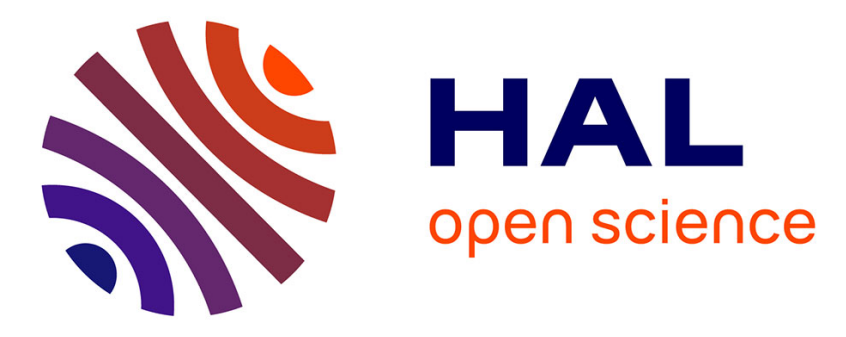

\title{
Crystal structure, physico-chemical and catalytic properties of two organic-inorganic hybrid polyoxometallate-based lanthanide complexes
}

Yassine Ghandour, Arbia Ben Khelifa, Mohamed Salah Belkhiria, Carole Daiguebonne, Stéphane Freslon, Olivier Guillou, Thierry Roisnel

\section{To cite this version:}

Yassine Ghandour, Arbia Ben Khelifa, Mohamed Salah Belkhiria, Carole Daiguebonne, Stéphane Freslon, et al.. Crystal structure, physico-chemical and catalytic properties of two organicinorganic hybrid polyoxometallate-based lanthanide complexes. Polyhedron, 2016, 115, pp.1-8. 10.1016/j.poly.2016.04.041 . hal-01322189

\section{HAL Id: hal-01322189 \\ https://hal.science/hal-01322189}

Submitted on 21 Jun 2016

HAL is a multi-disciplinary open access archive for the deposit and dissemination of scientific research documents, whether they are published or not. The documents may come from teaching and research institutions in France or abroad, or from public or private research centers.
L'archive ouverte pluridisciplinaire HAL, est destinée au dépôt et à la diffusion de documents scientifiques de niveau recherche, publiés ou non, émanant des établissements d'enseignement et de recherche français ou étrangers, des laboratoires publics ou privés. 


\title{
Crystal Structure, Physico-Chemical and Catalytic Properties of Two Organic-Inorganic Hybrid Polyoxometallate-Based Lanthanide Complexes.
}

Yassine Ghandour ${ }^{\mathrm{a} *}$, Arbia ben Khelifa ${ }^{\mathrm{a}}$, Mohamed Salah Belkhiria ${ }^{\mathrm{b}}$, Carole Daiguebonne ${ }^{\mathrm{c}}$ Stéphane Freslon ${ }^{c}$, Olivier Guillou ${ }^{\mathrm{c}}$ and Thierry Roisnel ${ }^{\mathrm{d}}$

${ }^{\mathrm{a}}$ Laboratoire de Physico-chimie des Matériaux, University of Monastir, Faculty of Sciences, Avenue de l'environnement, 5019 Monastir, Tunisia.

${ }^{\mathrm{b}}$ University of Sousse, High School of Sciences and Technology, Rue LamineAbassi, 4011 Hammam Sousse, Tunisia.

${ }^{\mathrm{c}}$ INSA, UMR 6226, Institut des Sciences Chimiques de Rennes, 35708 Rennes, France.

${ }^{\mathrm{d}}$ Centre de Diffractométrie X, UMR 6226, Institut des Sciences Chimiques de Rennes1, Campus de Beaulieu, 35042 Rennes Cedex, France

* Corresponding author: Tel: 00216-97209771 E-Mail: gandour_yassine@hotmail.fr

\begin{abstract}
Two organic-inorganic compounds based on Keggin anions and lanthanide ions have been synthesized. Their chemical formulae are $\left[\mathrm{Eu}\left(\mathrm{C}_{2} \mathrm{H}_{6} \mathrm{SO}\right)_{8}\right]\left[\mathrm{PMo}_{12} \mathrm{O}_{40}\right]$ (1) and $\left[\mathrm{Er}\left(\mathrm{C}_{2} \mathrm{H}_{6} \mathrm{SO}\right)_{8}\right]\left[\mathrm{PMo}_{12} \mathrm{O}_{40}\right] \cdot 2\left(\mathrm{C}_{2} \mathrm{H}_{6} \mathrm{SO}\right) \cdot 1 / 2 \mathrm{H}_{2} \mathrm{O}(2)$, respectively. They have been structurally characterized by single-crystal X-ray diffraction, IR, thermal analyses and cyclic voltammetry measurements. 1 and 2 crystallize in the space groups $\mathrm{P}-1$ and $\mathrm{P} 2{ }_{1} / \mathrm{c}$, respectively. Their catalytic activity toward organic dyes is quite sizeable since the target removal after $120 \mathrm{~min}$ is about $78.6 \%$ in the presence of the system $\left[\mathrm{Eu}\left(\mathrm{C}_{2} \mathrm{H}_{6} \mathrm{SO}\right)_{8}\right]\left[\mathrm{PMo}_{12} \mathrm{O}_{40}\right] / \mathrm{H}_{2} \mathrm{O}_{2}$ and $60.3 \%$ in the presence of the system $\left[\mathrm{Er}\left(\mathrm{C}_{2} \mathrm{H}_{6} \mathrm{SO}\right)_{8}\right]\left[\mathrm{PMo}_{12} \mathrm{O}_{40}\right] \cdot 2\left(\mathrm{C}_{2} \mathrm{H}_{6} \mathrm{SO}\right) \cdot 1 / 2 \mathrm{H}_{2} \mathrm{O} / \mathrm{H}_{2} \mathrm{O}_{2}$.
\end{abstract}

KEYWORDS: Polyoxomolybdates, Organic-inorganic hybrid, Crystal structure, Electrochemical properties, Catalytic activity. 


\section{INTRODUCTION}

In recent decades polyoxometallates have attracted great interest because of their wide range of topological properties and great potential for application in catalysis, photochemistry, electrochromism, magnetism and photocatalysis ${ }^{[1-4]}$. Actually, polyoxometallates can constitute excellent anionic precursors due to their controllable shapes and sizes, as well as their potential interest for the design of new materials with abundant chemical combinations and multiple functionalities ${ }^{[5-7]}$. Polyoxometallate clusters constitute a class of inorganic compounds that show a great variety of molecular structures ${ }^{[8]}$. This is due to the great versatility of their primary building components that allows chemists to link them in many different ways. Using specific reaction routes, recent insights into molybdenum-oxide based chemistry enable us, for instance, to construct spherically shaped molecular systems ${ }^{[9]}$. The overwhelming structural diversity of polyoxometallates thus provides not only molecular systems with original functionalities, but also a truly aesthetic appeal resulting from their amazing spatial structures and symmetries.

Lanthanide elements are hard acids in the classification of Pearson ${ }^{[10]}$ and, therefore, they are highly oxophilic ${ }^{[11,12]}$ with a greater affinity for ligands that have hard donor atoms than for those that have soft donor atoms. Recently, the syntheses of lanthanopolyoxometallates (LnPOMs) has received strong interest and the incorporation of lanthanide ions $\left(\mathrm{Ln}^{3+}\right)$ in polyoxometallatesis has become a focus in supramolecular chemistry because of their attractive physical properties, such as magnetic ${ }^{[13]}$ and optical properties ${ }^{[14]}$ which result from the synergy between the properties of the lanthanide ions and the POM clusters.

Here in, we describe the synthesis of two novel compounds :[Eu( $\left.\left.\mathrm{C}_{2} \mathrm{H}_{6} \mathrm{SO}\right)_{8}\right]\left[\mathrm{PMo}_{12} \mathrm{O}_{40}\right](\mathbf{1})$ and $\left[\mathrm{Er}\left(\mathrm{C}_{2} \mathrm{H}_{6} \mathrm{SO}\right)_{8}\right]\left[\mathrm{PMo}_{12} \mathrm{O}_{40}\right] \cdot 2\left(\mathrm{C}_{2} \mathrm{H}_{6} \mathrm{SO}\right) \cdot 1 / 2 \mathrm{H}_{2} \mathrm{O}(\mathbf{2})$. Their crystal structures were determined by single-crystal X-ray diffraction. They have also been 
analyzed by FT-IR spectroscopy, cyclic voltammetry and thermal analysis. Further, their ability for discoloration of solutions has been investigated. The effect of time was considered and the yield of color removal was calculated.

\section{EXPERIMENTAL SECTION}

All chemicals purchased were of reagent grade and used without further purification.

\section{Synthesis of compounds 1 and 2}

The $\left.\left[\left(\mathrm{C}_{4} \mathrm{H}_{9}\right)_{4} \mathrm{~N}\right)_{4}\right]\left[\mathrm{H}_{3} \mathrm{PMo}_{11} \mathrm{O}_{39}\right]$ starting material was prepared using the literature method (Combs-Walker et al., 1998) ${ }^{[15]}$.

$\left[\mathrm{Eu}\left(\mathrm{C}_{2} \mathrm{H}_{6} \mathrm{SO}\right)_{8}\right]\left[\mathrm{PMo}_{12} \mathrm{O}_{40}\right](\mathbf{1})$ and $\left[\mathrm{Er}\left(\mathrm{C}_{2} \mathrm{H}_{6} \mathrm{SO}\right)_{8}\right]\left[\mathrm{PMo}_{12} \mathrm{O}_{40}\right] \cdot 2\left(\mathrm{C}_{2} \mathrm{H}_{6} \mathrm{SO}\right) \cdot 1 / 2 \mathrm{H}_{2} \mathrm{O}(\mathbf{2})$

were prepared according to the procedure described in the literature ${ }^{[16]}$. A dimethylsulfoxide solution of $\mathrm{EuCl}_{3} \cdot 6 \mathrm{H}_{2} \mathrm{O}\left(\mathrm{ErCl}_{3} \cdot 6 \mathrm{H}_{2} \mathrm{O}\right.$ respectively $)$ and 2-hydroethylsalicylate $\left(\mathrm{C}_{9} \mathrm{H}_{10} \mathrm{O}_{4}\right)(1: 1$ molar ratio) was added dropwise to a yellow dimethylsulfoxide solution of $\left.\left[\left(\mathrm{C}_{4} \mathrm{H}_{9}\right)_{4} \mathrm{~N}\right)_{4}\right]\left[\mathrm{H}_{3} \mathrm{PMo}_{11} \mathrm{O}_{39}\right](0.33 \mathrm{mmol}$ in $10 \mathrm{~mL})$. The reaction mixture was then heated at 60 ${ }^{\circ} \mathrm{C}$ under stirring for 1 hour. Single crystals suitable for X-ray crystallographic studies were obtained by diffusion of 2-propanol through the dimethylsulfoxide solution.

\section{X-ray powder diffraction}

X-ray powder diagrams have been recorded by using a PanalyticalX'Pert Pro diffractometer with an $\mathrm{X}^{\prime}$ Celerator detector. The typical recording conditions were $45 \mathrm{kV}, 40$ $\mathrm{mA}$ for $\mathrm{CuK}_{\alpha}(\lambda=1.542 \AA)$, the diagrams were recorded in the $\theta-\theta$ mode over $60 \mathrm{~min}$, between 5 and $70^{\circ}$ with a step size of $0.0084^{\circ}$ and a scan time of $50 \mathrm{~s}$. The calculated patterns were produced using the Powdercell and Win PLOTR software programs ${ }^{[17,18]}$.

Experimental and simulated powder X-ray diffraction diagrams for $\mathbf{1}$ and $\mathbf{2}$ are reported in Figure S1. They support the mono phasic character of the samples. 


\section{Crystal structure determination}

Single crystals of $\mathbf{1}$ and $\mathbf{2}$ were mounted on an APEXII AXS-Bruker diffractometer equipped with a CCD camera and a graphite-monochromated $\operatorname{MoK}_{\alpha}$ radiation source $(\lambda=$ $0.71073 \AA$ A). Data were collected at $150 \mathrm{~K}$. Empirical absorption corrections were applied. Both crystal structures were solved by direct methods using the SIR-97 program ${ }^{[19]}$ and refined with the full-matrix least-squares method on $\mathrm{F}^{2}$ via the SHELXL-97 program ${ }^{[20]}$ and the WinGX interface ${ }^{[21]}$. All of non-hydrogen atoms were located in Fourier difference maps and were refined anisotropically. The crystal and final structure refinement data for $\mathbf{1}$ and $\mathbf{2}$ are listed in Table 1.

\begin{tabular}{lll}
\hline Table 1. Crystal and final structure refinement data for $\left[\mathrm{Eu}\left(\mathrm{C}_{2} \mathrm{H}_{6} \mathrm{SO}\right)_{8}\right]\left[\mathrm{PMo}_{12} \mathrm{O}_{40}\right](\mathbf{1})$ and \\
{$\left[\mathrm{Er}\left(\mathrm{C}_{2} \mathrm{H}_{6} \mathrm{SO}\right)_{8}\right]\left[\mathrm{PMo}_{12} \mathrm{O}_{40}\right] \cdot 2\left(\mathrm{C}_{2} \mathrm{H}_{6} \mathrm{SO}\right) \cdot 1 / 2 \mathrm{H}_{2} \mathrm{O}(\mathbf{2}) \cdot$} & $\mathrm{C}_{20} \mathrm{H}_{60} \mathrm{Er}_{1} \mathrm{Mo}_{12} \mathrm{O}_{50.5} \mathrm{P}_{1} \mathrm{~S}_{10}$ \\
\hline Empirical formula & $\mathrm{C}_{16} \mathrm{H}_{48} \mathrm{Eu}_{1} \mathrm{Mo}_{12} \mathrm{O}_{48} \mathrm{P}_{1} \mathrm{~S}_{8}$ & 2776.02 \\
Formula weight $\left(\mathrm{g} \mathrm{mol}^{-1}\right)$ & 2599.24 & Monoclinic \\
Crystal system & Triclinic & $\mathrm{P}_{1} / \mathrm{c}$ \\
Space group & $\mathrm{P}-1$ & $12.667(6)$ \\
$\mathrm{a}(\AA)$ & $11.6800(13)$ & $19.659(7)$ \\
$\mathrm{b}(\AA)$ & $12.0590(3)$ & $29.760(6)$ \\
$\mathrm{c}(\AA)$ & $22.359(3)$ & 90 \\
$\alpha\left({ }^{\circ}\right)$ & $84.414(4)$ & $91.971(15)$ \\
$\beta\left({ }^{\circ}\right)$ & $82.908(4)$ & 90 \\
$\gamma\left({ }^{\circ}\right)$ & $85.303(4)$ & $7406.5(5)$ \\
$\mathrm{V}\left(\AA^{3}\right)$ & $3127.5(6)$ & 150 \\
Temperature $(\mathrm{K})$ & 150 & 2 \\
$\mathrm{Z}$ & 2 & 5313 \\
$\mathrm{~F}(000)$ & 2476 & 3.475 \\
$\mu\left(\mathrm{mm}{ }^{-1}\right)$ & 3.699 & 59643 \\
$\mathrm{Ref.collected}$ & 41542 & $4573, \mathrm{R}_{\text {int }}=0.0834$ \\
Indep.Reflex & $10339, \mathrm{R}_{\text {int }}=0.05131$ & 1.053 \\
Goof $(\mathrm{S})$ & 1.173 & $6.49 \%$ \\
$\mathrm{R}_{1}[\mathrm{I}>2 \sigma(\mathrm{I})]$ & $4.89 \%$ &
\end{tabular}


$\mathrm{WR}_{2}[\mathrm{I}>2 \sigma(\mathrm{I})]$

$10.05 \%$

$16.70 \%$

CCDC Deposit number

1057824

1057913

$\mathbf{R}_{1}=\sum\left\|\mathbf{F}_{0}|-| \mathbf{F}_{\mathrm{c}}\right\| / \sum\left|\mathbf{F}_{0}\right| ; \mathbf{w R}_{2}=\left[\sum \mathbf{w}\left(\mathbf{F}_{\mathbf{0}}{ }^{2}-\mathbf{F}_{\mathbf{c}}{ }^{2}\right)^{2} / \sum \mathbf{w} \mathbf{F}_{0}{ }^{4}\right]^{1 / 2} ; \mathbf{S}=\left[\sum \mathbf{w}\left(\mathbf{F}_{\mathbf{0}}{ }^{2}-\mathbf{F}_{\mathbf{c}}{ }^{2}\right)^{2} /(\mathbf{n}-\mathbf{p})\right]^{1 / 2}$

\section{Thermal analyses}

Thermal analyses were performed in platinum crucibles under a nitrogen atmosphere between room temperature and $800{ }^{\circ} \mathrm{C}$ with a heating rate of $10{ }^{\circ} \mathrm{C} \mathrm{min}{ }^{-1}$ using a PerkinElmer Pyris Diamond thermal analyzer

\section{FT-IR spectroscopy}

FT-IR spectra were recorded in the range $400-4000 \mathrm{~cm}^{-1}$ on a Nicolet 470 FT-IR spectrophotometer on pressed $\mathrm{KBr}$ pellets. IR spectra of $\mathbf{1}$ and $\mathbf{2}$ are very similar. Both present (Figure S2) the characteristic peaks of the $\alpha$-Keggin anion $\left[\mathrm{PMo}_{12} \mathrm{O}_{40}\right]^{3-}$, namely $v(\mathrm{P}-\mathrm{Oa})$, v(Mo-Od), v(Mo-Ob-Mo) and v(Mo-Oc-Mo) at 1064, 960, 876 and $798 \mathrm{~cm}^{-1}$ respectively ${ }^{[22]}$. The feature band at $1009 \mathrm{~cm}^{-1}$ can be ascribed to the $v(\mathrm{~S}=\mathrm{O})$ asymmetric stretching vibration of DMSO molecules. Compared with free DMSO, the $v(\mathrm{~S}=\mathrm{O})$ shift from 1055 to $1009 \mathrm{~cm}^{-1}$ supports that the DMSO ligands are coordinated to the metal ions by the oxygen atoms ${ }^{[23]}$.

\section{Electrochemical measurements}

Cyclic voltammetry experiments on both complexes were carried out in $0.1 \mathrm{M}$ $\mathrm{Bu}_{4} \mathrm{NPF}_{6} / \mathrm{DMSO}$ solutions under an argon atmosphere, with the potential ranging from -2000 to $1500 \mathrm{mV}$ at a scan rate of $50 \mathrm{mV} \mathrm{s}^{-1}$. The electrochemical measurements were performed using a Potentiostat Galvanostat instrument (Voltalab 40). The electrochemical measurements were performed using three-electrode cell (volume $5 \mathrm{~mL}$ ) containing a glassy carbon electrode (geometrical surface $0.07 \mathrm{~cm}^{2}$ ) as the working electrode, a $(\mathrm{Ag} / \mathrm{AgCl})$ electrode as the reference electrode and a platinum wire as the counter electrode. All the electrochemical measurements were carried out in a Faraday cage at room temperature to avoid external interference which could perturb the impedance response. 


\section{Catalytic study}

$0.05 \mathrm{~g}$ of either $\left[\mathrm{Eu}\left(\mathrm{C}_{2} \mathrm{H}_{6} \mathrm{SO}\right)_{8}\right]\left[\mathrm{PMo}_{12} \mathrm{O}_{40}\right]$ or $\left[\operatorname{Er}\left(\mathrm{C}_{2} \mathrm{H}_{6} \mathrm{SO}\right)_{8}\right]\left[\mathrm{PMo}_{12} \mathrm{O}_{40}\right] \cdot 2\left(\mathrm{C}_{2} \mathrm{H}_{6} \mathrm{SO}\right)$

- $1 / 2 \mathrm{H}_{2} \mathrm{O}$ were added to $50 \mathrm{~mL}$ of the organic dye solution, followed by the addition of a calculated dose of $\mathrm{H}_{2} \mathrm{O}_{2}$. The experiments were carried out in a batch system for $120 \mathrm{~min}$ and were uniformly agitated at a speed of $150 \mathrm{rpm}$. At the end of the chosen contact time, the content of the flasks were filtered using a Whatman No. 41 filter paper. The concentration of the dye in each filtrate was determined at the maximum wavelength $(620 \mathrm{~nm})$.

\section{RESULTS AND DISCUSSION}

The crystal structures of both compounds $\mathbf{1}$ and $\mathbf{2}$ are based on the centrosymetric hetero-polyanion $\left[\mathrm{PMo}_{12} \mathrm{O}_{40}\right]^{3-}$ and consist of a $\alpha$-Keggin structure in which a central tetrahedron of $\mathrm{PO}_{4}$ is surrounded by twelve $\mathrm{MoO}_{6}$ octahedrons, arranged in four groups of three edge-shared octahedral $\mathrm{Mo}_{3} \mathrm{O}_{13}$ units. These groups are connected to one another by their vertices. Bond valence sum calculations (BVSC) ${ }^{[24]}$ confirm that all the molybdenum atoms present $\mathrm{a}+\mathrm{VI}$ oxidation state, the phosphorus atom presents $\mathrm{a}+\mathrm{V}$ oxidation state and the erbium or europium atom presents a +III oxidation state.

\section{Crystal structure of $\left[\mathrm{Eu}\left(\mathrm{C}_{2} \mathrm{H}_{6} \mathrm{SO}\right)_{8}\right]\left[\mathrm{PMo}_{12} \mathrm{O}_{40}\right](1)$}

Compound 1 crystallizes in the triclinic system, space group P-1. Relevant crystal data and structural refinement parameters are listed in Table 1 . The asymmetric unit consists of two half $\left[\mathrm{PMo}_{12} \mathrm{O}_{40}\right]^{3-}$ anions and one $\left[\mathrm{Eu}(\mathrm{dmso})_{8}\right]^{3+}$ cation. The $\mathrm{P} 1$ and $\mathrm{P} 2$ atoms are located on inversion centers and the central four $\mu_{4}$-oxygen atoms are disordered over eight positions with each oxygen site half occupied. The P-O bond lengths range from 1.438 to $1.663 \AA$, while the Mo-O distances can be grouped into three sets: Mo- $\mathrm{O}_{\mathrm{t}}$ from 1.630 to $1.672 \AA$, Mo$\mathrm{O}_{\mathrm{c}}$ from 2.422 to $2.523 \AA$ and Mo- $\mathrm{O}_{\mathrm{b}}$ from 1.819 to $2.135 \AA^{[25]}$. 
The europium complex cation contains one $\mathrm{Eu}(\mathrm{III})$ center that is eight coordinated by eight oxygen atoms that belong to eight different dimethylsulfoxide molecules (Figure 1).

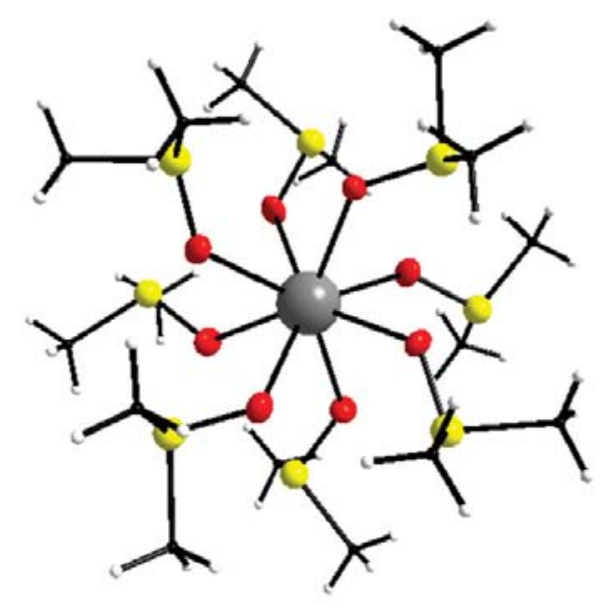

Figure 1. Coordination environment of the europium ion in $\left[\mathrm{Eu}\left(\mathrm{C}_{2} \mathrm{H}_{6} \mathrm{SO}\right)_{8}\right]\left[\mathrm{PMo}_{12} \mathrm{O}_{40}\right]$.

The Eu-O distances range from 2.345 to $2.435 \AA$. The $\left[\mathrm{Eu}(\mathrm{dmso})_{8}\right]^{3+}$ complexes and $\left[\mathrm{PMo}_{12} \mathrm{O}_{40}\right]^{3-}$ Keggin anions alternate: each cationic Eu-based complex can be described as being located at the center of a square whose vertexes are occupied by Keggin anions, and vice versa. In this crystal structure there are $\alpha$-Keggin anions stack parallel to the three crystallographic axes and the Eu complexes are located between the $\alpha$-Keggin anions (Figure 2). As shown in Figure 3, the crystal packing is ensured by complex non-typical C-H..... network contact interactions (non-conventional H-bonds) ${ }^{[26]}$. Selected C-H...O distances are listed in Table S1. 


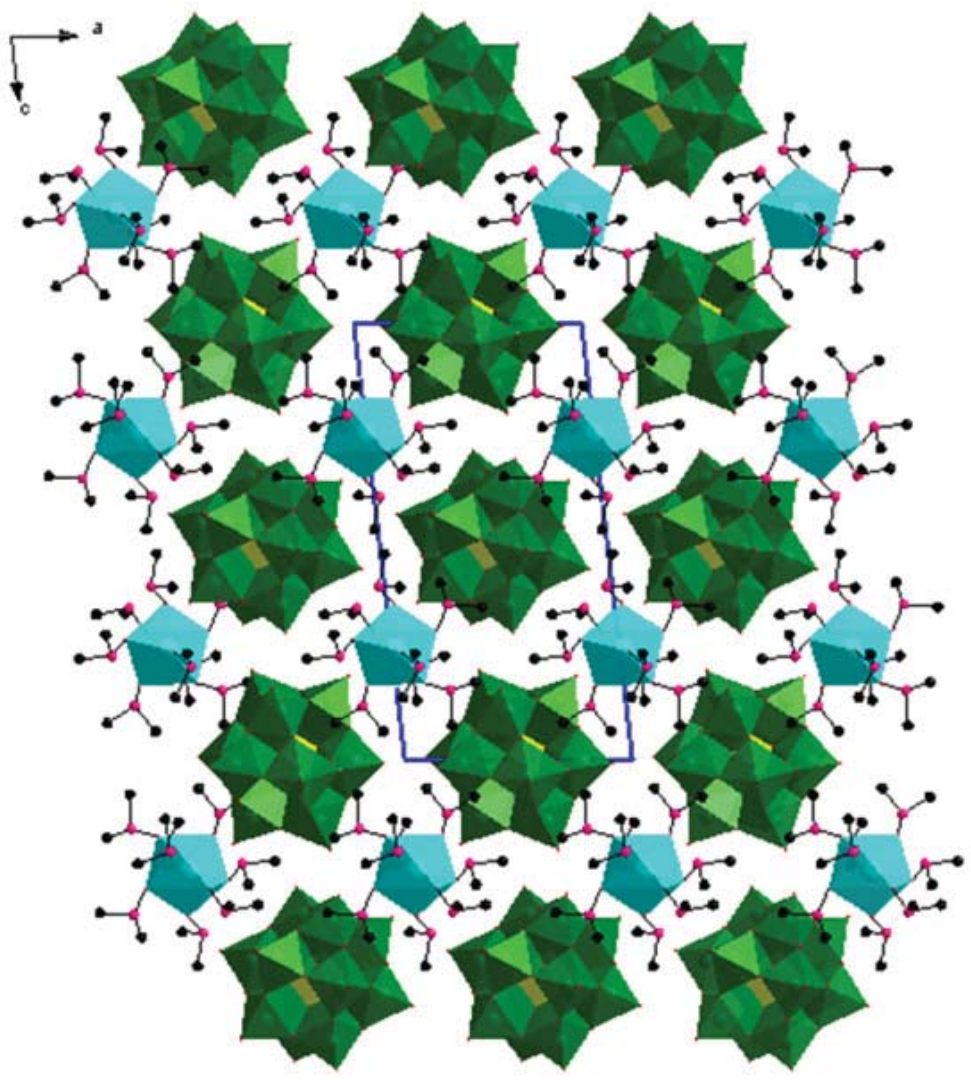

Figure 2. Projection of the view along the $b$ axis of a polyhedral representation of the supramolecular structure of $\left[\mathrm{Eu}\left(\mathrm{C}_{2} \mathrm{H}_{6} \mathrm{SO}\right)_{8}\right]\left[\mathrm{PMo}_{12} \mathrm{O}_{40}\right](\mathbf{1})$.

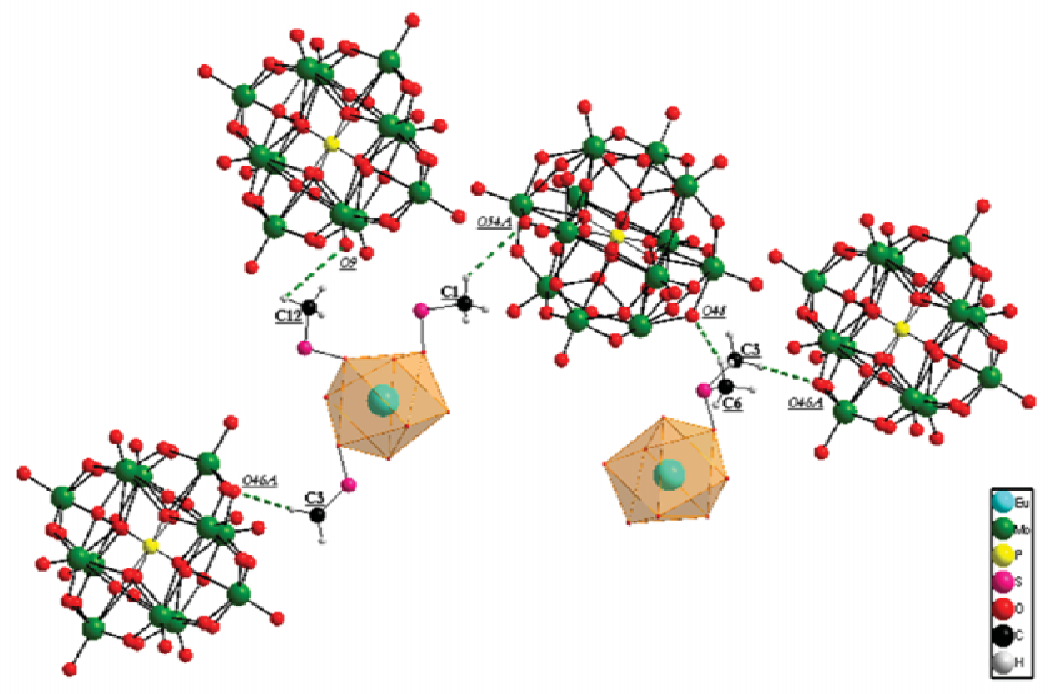

Figure 3. Environment of the Keggin anions and H-bonds in compound $\mathbf{1 .}$ 
Calculations with SHAPE software ${ }^{[27]}$ indicate that the europium coordination polyhedron is best described by a triangular dodecahedron with the $D_{2 d}$ symmetry group ${ }^{[28]}$ (Figure 4). The inner coordination sphere parameters of the europium ions are given in Table 2. The skew angle $\Phi$, defined as the offset between the two faces of the coordinating polyhedron, is $79.95^{\circ}$. The interplanar distance $d_{p p}$, calculated as the distance between the upper and lower planes containing each four oxygen atoms, ranges from 2.2676 to $3.0453 \AA$ (mean value $2.621 \AA$ ) for compound $\mathbf{1}$. The average distance between the four neighboring oxygen atoms placed in each plane, $d_{i n}$, is found to be $2.841 \AA$ and $\varphi$, the angle between the planes normal vectors, is $5.107^{\circ}$.
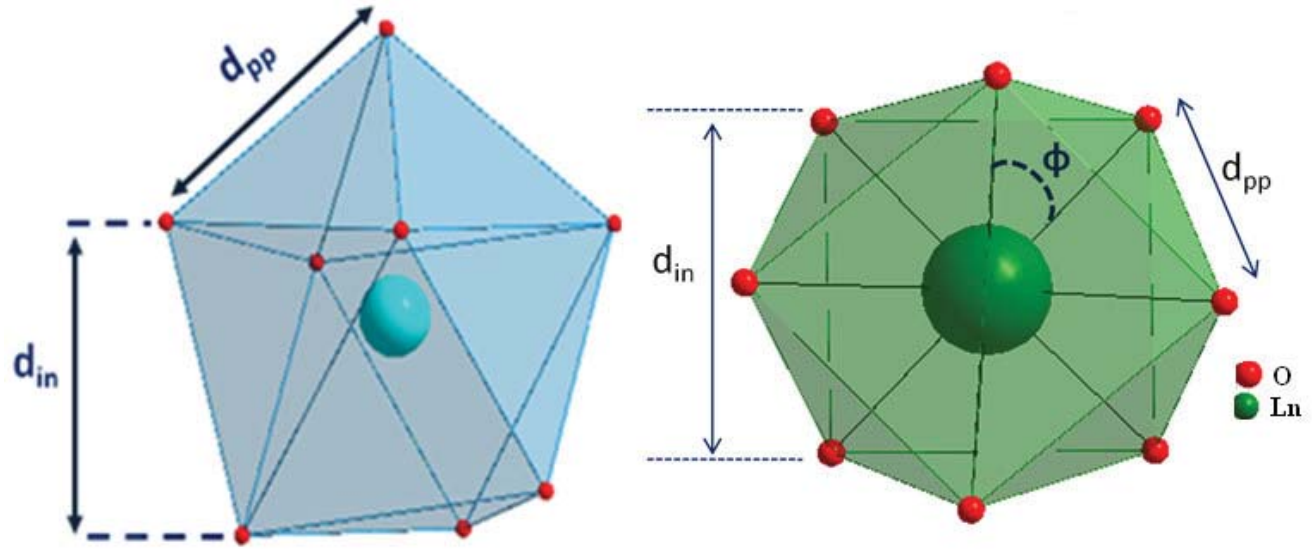

Figure 4. Coordination polyhedron and its geometric parameters for the lanthanide ion.

Table.2. Structural parameters of the lanthanide coordination sphere in compounds $\mathbf{1}$ and $\mathbf{2}$.

\begin{tabular}{ccccccc}
\hline Polyhedron & Symmetry & $\mathrm{d}_{\mathrm{in}}(\AA)$ & $\mathrm{d}_{\mathrm{pp}}(\AA)$ & $\varphi\left(^{\circ}\right)$ & $\Phi\left(^{\circ}\right)$ & Ln-O $(\AA)$ \\
\hline $\mathrm{Eu}$ & $\mathrm{D}_{2 \mathrm{~d}}$ & $2.841(8)$ & $2.621(8)$ & 5.107 & $79.947(1)$ & $2.399(3)$ \\
$\mathrm{Er}$ & $\mathrm{D}_{4 \mathrm{~d}}$ & $2.786(9)$ & $2.544(9)$ & 0.609 & $78.220(1)$ & $2.345(4)$
\end{tabular}




\section{Crystal structure of $\left[\mathrm{Er}\left(\mathrm{C}_{2} \mathrm{H}_{6} \mathrm{SO}\right)_{8}\right]\left[\mathrm{PMo}_{12} \mathrm{O}_{40}\right] \cdot 2\left(\mathrm{C}_{2} \mathrm{H}_{6} \mathrm{SO}\right) \cdot 1 / 2 \mathrm{H}_{2} \mathrm{O}(2)$}

Compound 2 crystallizes in the monoclinic system, space group $\mathrm{P} 2{ }_{1} / \mathrm{c}$. The unit cell contain consists of one erbium complex $\left[\operatorname{Er}(\mathrm{dmso})_{8}\right]^{3+}$ cation, two crystallization dimethylsulfoxide molecules, a half water molecule and one anionic $\left[\mathrm{PMo}_{12} \mathrm{O}_{40}\right]^{3-}$ cluster (Figure 5).

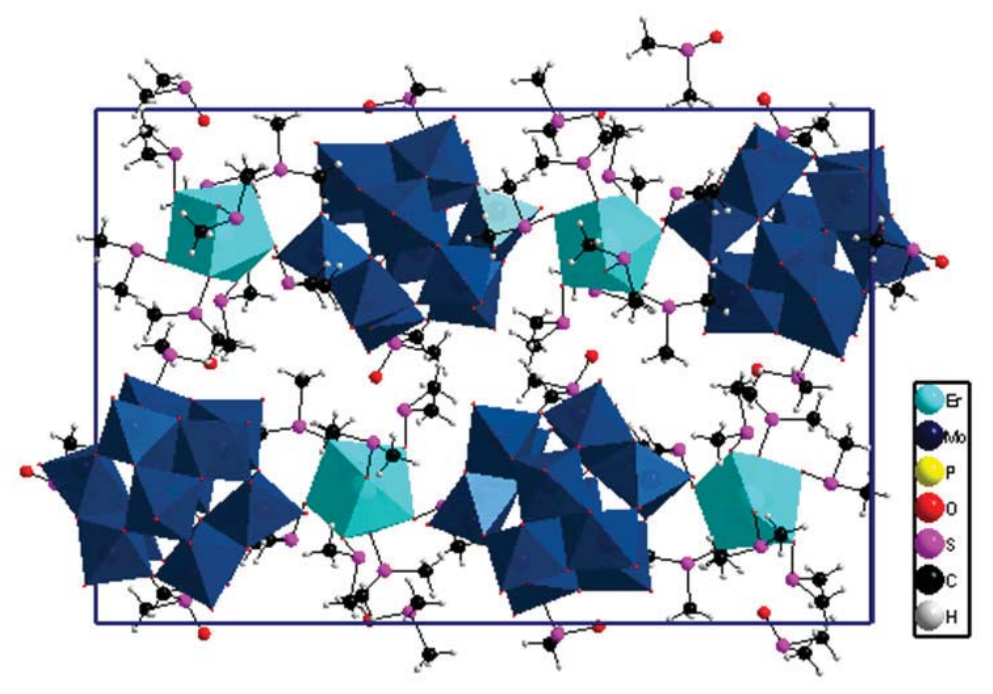

Figure 5. Projection view along the $a$ axis of an extended unit cell of

$\left[\mathrm{Er}\left(\mathrm{C}_{2} \mathrm{H}_{6} \mathrm{SO}\right)_{8}\right]\left[\mathrm{PMo}_{12} \mathrm{O}_{40}\right] \cdot 2\left(\mathrm{C}_{2} \mathrm{H}_{6} \mathrm{SO}\right) \cdot 1 / 2 \mathrm{H}_{2} \mathrm{O}(2)$.

In $\left[\mathrm{PMO}_{12} \mathrm{O}_{40}\right]^{3-}$, the phosphorus atom lays on an inversion center and the central four oxygen atoms are disordered over eight positions with each oxygen site half-occupied. The title compound consists of a $3 \mathrm{D}$ network in which $\left[\mathrm{PMo}_{12} \mathrm{O}_{40}\right]^{3-}$ polyanions and $\left[\mathrm{Er}(\mathrm{dmso})_{8}\right]^{3+}$ cations alternate (Figure 6). The crystal packing is ensured by hydrogen bonds that involve Er-based complexes and crystallization solvent molecules and by a complex non-typical CH..... network contact interactions (Figure 7 and Table S2). 


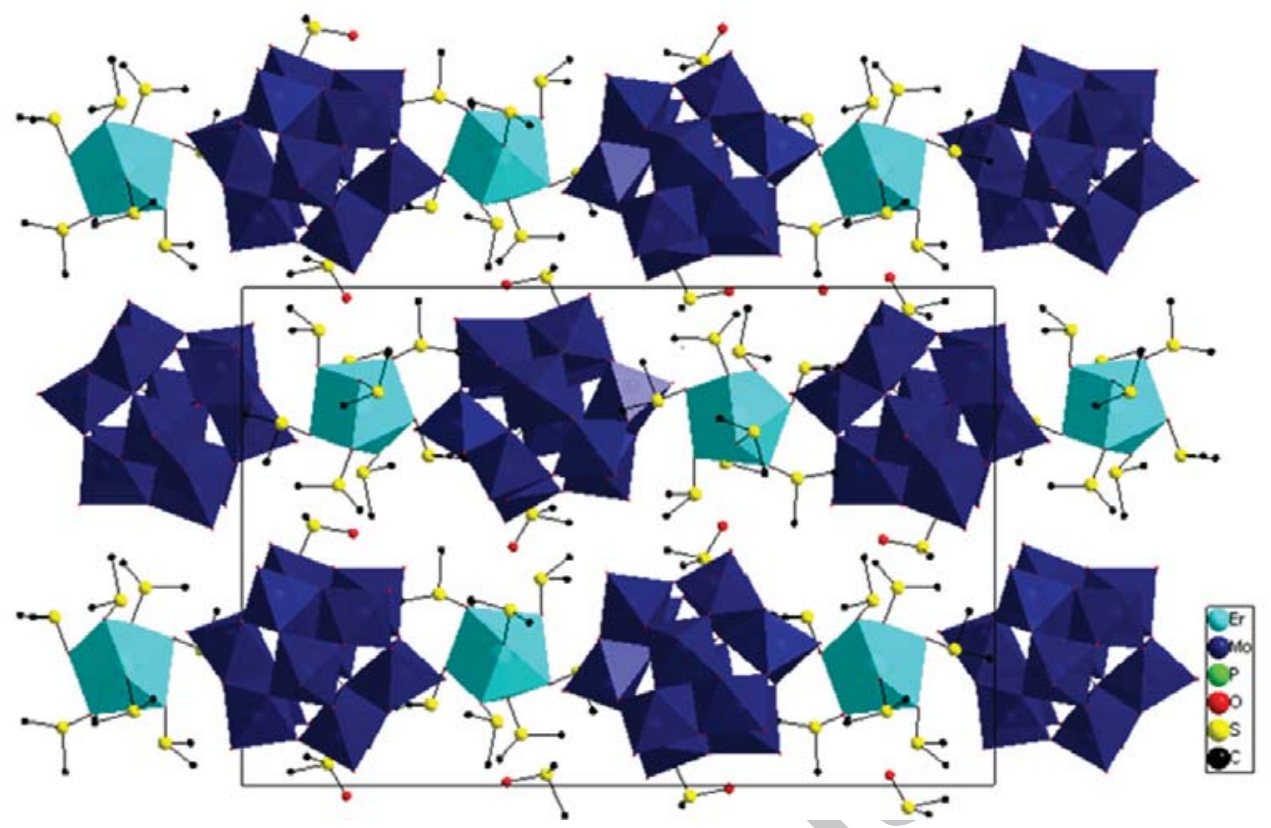

Figure 6. Projection view along the $a$ axis of $\left[\mathrm{Er}\left(\mathrm{C}_{2} \mathrm{H}_{6} \mathrm{SO}\right)_{8}\right]\left[\mathrm{PMo}_{12} \mathrm{O}_{40}\right] .2\left(\mathrm{C}_{2} \mathrm{H}_{6} \mathrm{SO}\right) \cdot 1 / 2 \mathrm{H}_{2} \mathrm{O}$.

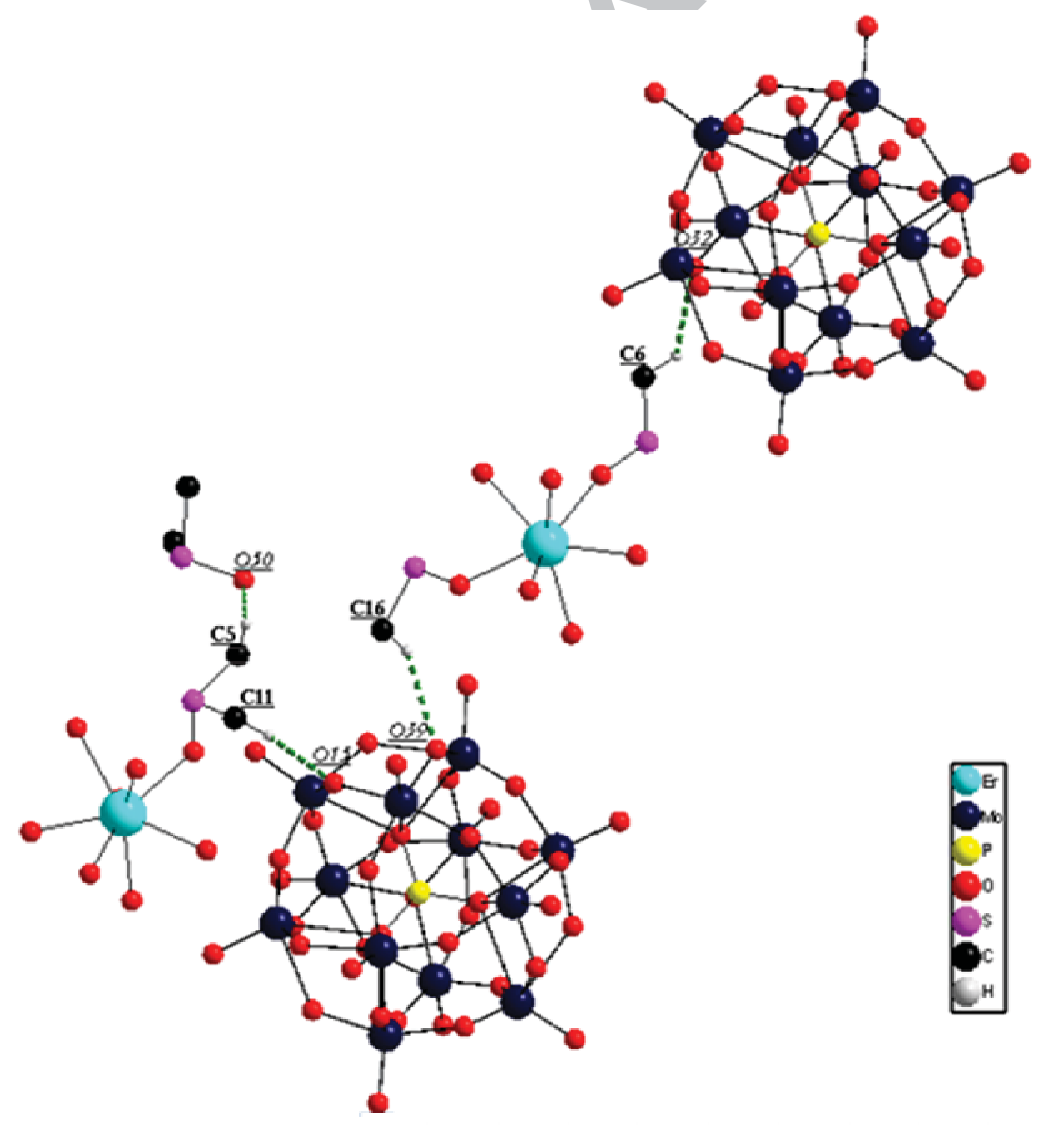

Figure 7. Environment of the Keggin anions and H-bonds in compound (2). 
Calculations with SHAPE software ${ }^{[27]}$ indicate that the $\mathrm{Er}^{3+}$ coordination polyhedron is best described by a square antiprism with $\mathrm{D}_{4 \mathrm{~d}}$ symmetry ${ }^{[19]}$. The skew angle $\Phi$ is $78.22^{\circ}$, the interplane distance $d_{p p}$ ranges from 2.2676 to $3.0453 \AA$ (mean value $2.544 \AA$ ), the mean distance between the four neighboring oxygen atoms placed in each plane $\mathrm{d}_{\text {in }}$ is $2.786 \AA$ and the $\varphi$ angle between the planes normal vectors is 0.609 (Table 2).

\section{Thermal analyses}

The thermal behaviors of both compounds were studied. As shown by the TGA-TDA curves of compound 1 (Figure S3), the first weight loss of $25.45 \%$ (calc.24.04\%) in the temperature range $140-300{ }^{\circ} \mathrm{C}$, with two endothermic peaks at 210 and $270^{\circ} \mathrm{C}$ and one exothermic peak at $295{ }^{\circ} \mathrm{C}$, can be attributed to the loss of eight dimethylsulfoxide molecules and the decomposition of the complexes. The second weight loss at $510{ }^{\circ} \mathrm{C}$ is attributed to the collapse of the Keggin structure ${ }^{[2]}$

The thermogram of compound 2 (Figure S4), exhibits two steps of weight losses, 15.54 and $13.04 \%$ (in total $28.58 \%$ ) in the temperature range $100-320{ }^{\circ} \mathrm{C}$ with three endothermic peaks at 125,165 and $297^{\circ} \mathrm{C}$ that can be attributed to the departure of crystallization and coordination dimethylsulfoxide and water molecules (calc. 28.4\%). The weight loss with endothermic peaks at $530{ }^{\circ} \mathrm{C}$ can be attributed to the disruption of the Keggin poly-anion.

\section{Electrochemical behavior}

The electrochemical measurements were carried out in dimethylsulfoxide solution $\left(10^{-3} \mathrm{M}\right)$ under an argon atmosphere at room temperature. The cyclic voltammetry realized for compound 1 (Figure 8a) presents three reduction waves. The first reversible reduction (I, I') at 
$-0.02,-0.19 \mathrm{~V}$ with half-potentials at $-97 \mathrm{mV}$ ( $\mathrm{vs} \mathrm{Ag} / \mathrm{AgCl}$ ) is attributed to the redox proprieties of the molybdenum center $\left(\mathrm{Mo}^{\mathrm{IV}} / \mathrm{Mo}^{\mathrm{V}}\right)$ in the $\mathrm{POM}{ }^{[30]}$. The two other reductions (R1) and (R2) observed around -0.72 and $-1.45 \mathrm{~V}$, respectively, are ascribed to the redox process of the europium centers ${ }^{[31]}$.

The voltamogram of compound $\mathbf{2}$, (Figure 8b) presents two redox peaks. The first one is similar to the first one observed for complex $\mathbf{1}$, with half-potentials at $-86 \mathrm{mV}$ and is attributed to the redox proprieties of the molybdenum center $\left(\mathrm{Mo}^{\mathrm{IV}} / \mathrm{Mo}^{\mathrm{V}}\right)^{[28]}$. The second redox wave, characterized by a cathodic peak (Epc) at $-1.29 \mathrm{~V}(\mathrm{vs} \mathrm{Ag} / \mathrm{AgCl})$ and an anodic wave (Epa) at $-1.04 \mathrm{~V}$, is attributed to the redox processes of the erbium centers.
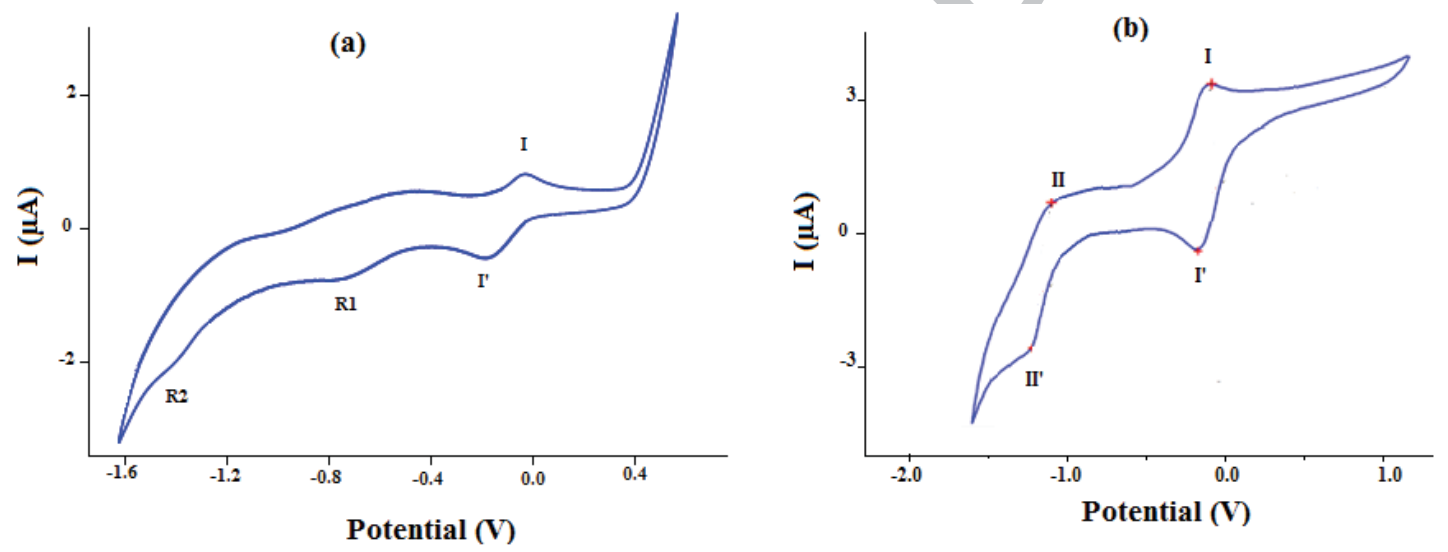

Figure 8. Cyclic voltammetry of compounds $\mathbf{1}$ (a) and $\mathbf{2}$ (b) recorded in presence of $\mathrm{Bu}_{6} \mathrm{NPF}_{6}$ $\left(0.1 \mathrm{~mol} \mathrm{~L}^{-1}\right)$ in DMSO.

\section{Application to the degradation of organic dyes}

According to the literature, only a few POM-based compounds have been investigated for their efficiency in the degradation of textile dyes. For example the works of Lei Li et al; have concentrated on the synthesis of $\left[\mathrm{Ag}_{3} \mathrm{~L}_{4}\left(\mathrm{PMo}_{12} \mathrm{O}_{40}\right)\left(\mathrm{CH}_{3} \mathrm{OH}\right)\right] \cdot \mathrm{CH}_{3} \mathrm{OH}$ and its photocatalytic performance for the degradation of rhodamine $\mathrm{B}^{[32]}$. In the other hand, Jabli et al., [33] reported an investigation concerning the immobilization of either [bis(2methylallyl)(1,5-cyclooctadienne) ruthenium(II)] or ruthenium chloride $\left(\mathrm{RuCl}_{3}\right)$ on chitosan 
microspheres and heterogeneous catalysis reactions were used for the oxidative degradation of two acid dyes (Calmagite and Acid Blue 25 in aqueous solution in the presence of hydrogen peroxide). These studies show that Calmagite, containing an azo bond, is more easily degraded than Acid Blue 25.

In our present work, we have investigated the degradation of Naphthol Blue Black solutions using compounds 1 and 2 (Figure 9). A clear decrease of the absorbance value is observed in both cases.
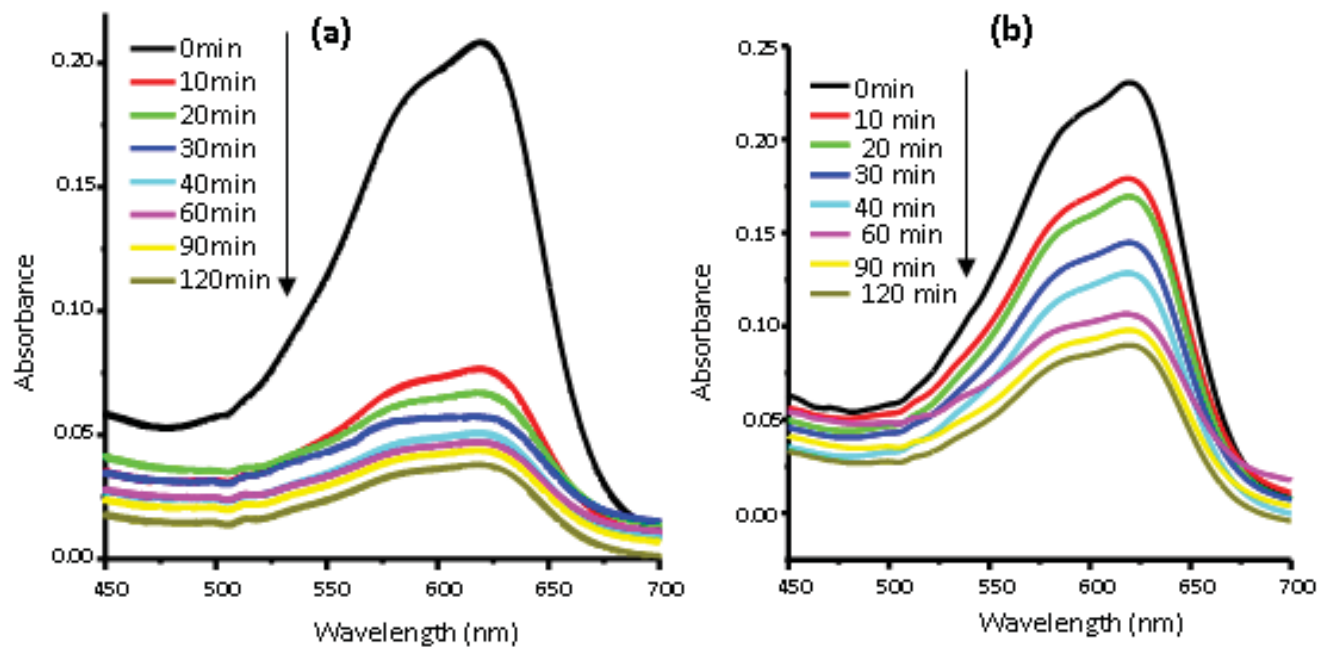

Figure 9. Absorbance versus time of Naphthol Blue Black solutions in the presence of the systems $1 / \mathrm{H}_{2} \mathrm{O}_{2}$ (a) and $2 / \mathrm{H}_{2} \mathrm{O}_{2}$ (b).

Naphthol Blue Black is a stable and persistent dye in the presence of an oxidant agent $\left(\mathrm{H}_{2} \mathrm{O}_{2}\right.$ ) alone (Figure 10). However, the combination of either compound $\mathbf{1}$ or $\mathbf{2}$ with $\mathrm{H}_{2} \mathrm{O}_{2}$ led to the decolorization of the dye solution. It is also noticeable that the rate of the decolorization increases rapidly with time. As an example, after only $10 \mathrm{~min}$, the removal of the color reaches $62 \%$ using the system $1 / \mathrm{H}_{2} \mathrm{O}_{2}$. After equilibrium, removal reaches about $78.6 \%$ in the presence of the system $1 / \mathrm{H}_{2} \mathrm{O}_{2}$ and $60.3 \%$ in the presence of the system $2 / \mathrm{H}_{2} \mathrm{O}_{2}$. 


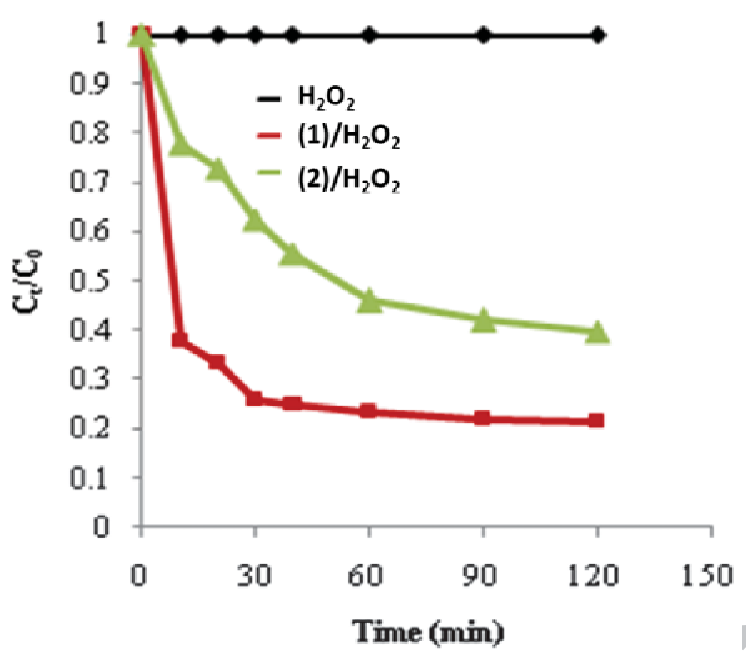

Figure10. Relative integrated intensity of the absorption spectra versus time of Naphthol Blue Black solutions.

\section{CONCLUSION}

Two hybrid polyoxometallate-based compounds with lanthanides ions have been successfully synthesized and structurally characterized. The electrochemical study of compounds 1 and 2 shows a reversible reduction peak around $-0.42 \mathrm{~V}$, attributed to the dodecamolybdate cluster, and a process reduction attributed to the lanthanide ions. These compounds exhibit remarkable yields for the degradation of Naphthol Blue Black solutions, which has been chosen as a model for organic dyes. In fact, the removal exceeds, respectively, 60 and $80 \%$ for compounds 1 and 2 after 2 hours of reaction.

\section{SUPPORTING INFORMATION.}

Further details of the crystal structure investigation can be obtained free of charge via http:/www.ccdc.cam.ac.uk/data_request/cif, by e-mailing data_request@ccdc.cam.ac.uk or by contacting The Cambridge Crystallographic Data Centre, 12 Union Road, Cambridge CB2 
1EZ, UK. Fax: +44 1223 336033. The depository numbers are CCDC 1057824 and 1057913 for $\mathbf{1}$ and $\mathbf{2}$, respectively.

Experimental and simulated powder X-ray diffraction patterns for compounds $\mathbf{1}$ and $\mathbf{2}$

(Figure S1); $\quad$ FT-IR spectra of $\quad\left[\mathrm{Eu}\left(\mathrm{C}_{2} \mathrm{H}_{6} \mathrm{SO}\right)_{8}\right]\left[\mathrm{PMo}_{12} \mathrm{O}_{40}\right] \quad$ and $\left[\mathrm{Er}\left(\mathrm{C}_{2} \mathrm{H}_{6} \mathrm{SO}\right)_{8}\right]\left[\mathrm{PMo}_{12} \mathrm{O}_{40}\right] \cdot 2\left(\mathrm{C}_{2} \mathrm{H}_{6} \mathrm{SO}\right) \cdot 1 / 2 \mathrm{H}_{2} \mathrm{O}$ (Figure $\mathrm{S} 2$ ); Non-typical contact interaction geometries in 1 (Table S1); Non-typical contact interaction geometries in $\mathbf{2}$ (Table S2); Thermal analysis of compound 1 (Figure S3); Thermal analysis of compound 2 (Figure S4).

\section{ACKNOWLEDGMENTS}

This work was supported by the "Laboratory Physico-chimie of Materials, University of Monastir" and the ministry of higher education and scientific research of Tunisia.

\section{REFERENCES}

[1] (a) M. T. Pop, Heteropoly and Isopolyoxometallates: Springer,Berlin (1983).

(b) C. L. Hill, Chem. Rev. 98 (1998) 1.

(c) C. L. Hill, C. M. P. McCartha, Coord. Chem. Rev. 143 (1995) 407.

(d) S. S. Wang, G. Y. Yang, Chem. Rev. 115 (2015) 4893.

[2] (a) A. Muller, S.Q. Shah, H. Bogge, N. Schmidtmann, Nature 48 (1999) 397.

(b) P. Mialane, A. Dolbecq, J. Marrot, E. Riviere, F. Secheresse, Angew. Chem, Int. Ed 42 (2003) 3523.

(c) K. von Allmen, R. Moré, R. Muller, J. S. Lopez, A. Linden, G. R. Patzke, ChemPlusChem. 80 (2015) 1389.

[3] (a) L. Chen, F. L. Jiang, Z. Z. Lin, Y. F. Zhou, C. Y. Yue, M.C. Hong, J. Am. Chem. Soc. $127(2005) 8588$.

(b) J. W. Liu, Y. C. Liu, H. He, B. F. Yang, G. Y. Yang, Inorg. Chem. Commun. 53 (2015) 60.

(c) P. Mialane, G. Zhang, I. M. Mbomekalle, P. Yu, J. D. Compain, A. Dolbecq, J. Marrot, F. Secheresse, B. Keita, L. Nadjo, Chem. Eur. J. 16 (2010) 5572.

[4] C. G. Liu, T. Zheng, S. Liu, Han-Yu Zhang, J. Mol. Struct.1110 (2016) 44. 
[5] A. Dolbecq, E. Dumas, C. R. Mayer, P. Mialane, Chem. Rev. 110 (2010) 6009.

[6] H. J. Peng, J. Peng, C. J. Zhang, Y. G. Li, P. P. Zhang, H. Y. Ma,Z. M. Su, Chem. Commun. 46 (2010) 5097.

[7] L. M. Dai, W. S. You, Y. G. Li, E. B. Wang, Y. Huang, Chem. Commun. (2009) 2721.

[8] (a) M. T. Pop, A. Muller, Angew. Chem. Int. Ed. Engl. 30 (1991) 34.

(b) A. Muller, F. Peters, M. T. Pop, D. Gatteschi, Chem. Rev. 98 (1998) 239.

[9] A. Müller, P. Kögerler, H. Bögge, Struct. Bond. 96 (2000) 203.

[10] A. Müller, S. Q. N. Shah, H. Bögge, M. Schmidtmann, Nature 397 (1997) 48.

[11] R. C. Howell, F. G. Perez, S. Jain, W. D. Horrocks, A. L. Rheingold, L. C. Francesconi, Angew. Chem. Int. Ed. 40 (2001) 4031.

[12] J. M. Lehn, Supramolecular Chemistry: Concepts and Perspectives. VCH, Weinheim, Germany (1995)

[13] S. Saha, P. P. Jana, C. J. Gomez-Garcia, K. Harms, H. P. Nayek, Polyhedron. 104 (2016) 58.

[14] V. Goovaerts, K. Stroobants, G. Absillis, T. N. Parc-Vogt, J. Inorg. Biochem.150 (2015) 72.

[15] A. Lucille, Combs-Walker, C. L. Hill, Inorg. Chem. 30 (1991) 4016.

[16] A. Ben Khélifa, M. Giorgi, M. S. Belkhiria, Acta Cryst. E68 (2012) 938.

[17] W. Kraus, G. Nolze, J. Appl. Crystallogr. 29 (1996) 301.

[18] T. Roisnel, J. Rodriguez-Carjayal, Mater. Sci. Forum 118 (2001) 378

[19] A. Altomare, G. Cascarano, C. Giacovazzo, A. Gualardi, J. Appl. Cryst.26 (1993) 343.

[20] G. M. Sheldrick, Acta Cryst .A64 (2008) 112.

[21] L. J. Farrugia, J.Appl.Crystallogr. 45 (2012) 849.

[22] W. Zhou, X. Fêng, H. Ke, Y. Li, J. Tang, E. Wang, Inorg. Chem. Acta. 394 (2013) 770.

[23] J. Y. Niu, M. L. Wei, J. P. Wang, J. Mol. Struct. 689 (2004) 147.

[24] I. D. Brown, D. Altermatt, Acta Cryst. Sect. B.41 (1985) 244.

[25] J. Y. Niu, Q. Wu, J. P. Wang, J. Chem. Soc., Dalton Trans. 12 (2002) 2512.

[26] D. J. Sutor, Nature 195 (1962) 68.

[27] S. Alvarez, P. Alemany, D. Casanova, J. Cirera, M. Llumell, D. Avnir, Coord. Chem. Rev. 249 (2005) 1693.

[28] D. Casanova, M. Llunell, P. Alemany, S. Alvarez, Chem. Eur. J. 11 (2005) 1479.

[29] M. Masteri-Farahani, S. Shahbazi, Inorg. Chem. Commun. 15 (2012) 297. 
[30] S. Gatard, S. Blanchard, B. Schollhom, P. Gouzerh, A. Proust, K. Boubakeur, Chem. Eur. J. 16 (2010) 8390.

[31] T. Nyokong, F. Furuya, N. Kobayshi, D. Du, W. Liu, J. Jiang, Inorg. Chem. 39 (2000) 128.

[32] Lei Li, M. Cheng, Y. Bai, B. An, D. Dang, Spectrochim. Acta Part A.150 (2015) 846.

[33] M. Jabli, R. Touati, Y. Kacem, B. Ben Hassine, J. Textile Institute 103 (2012) 434. 

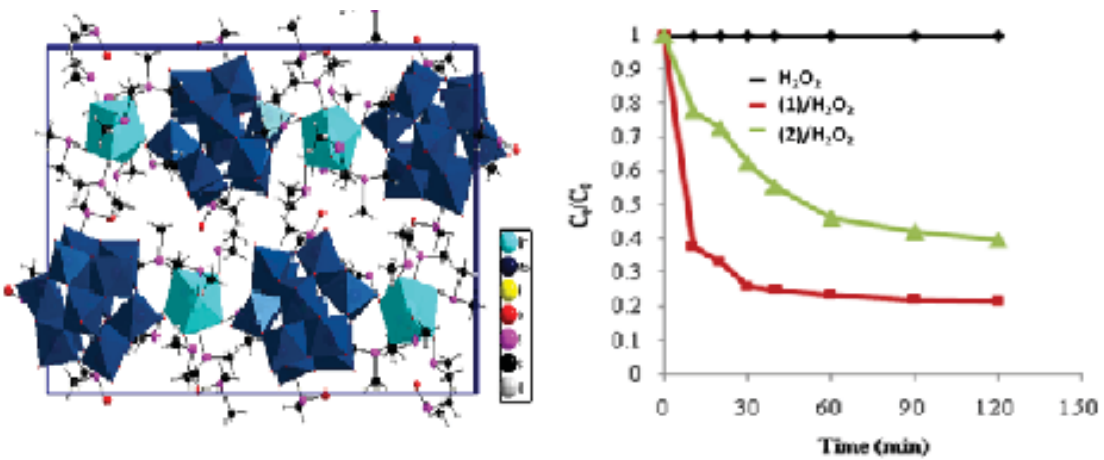

Two hybrid poly-oxo-metalate-based compounds with lanthanides ions have been successfully synthesized and structurally characterized. The dectrochemical study of compounds (1) and (2) shows a reversible reduction peak around - $0.42 \mathrm{~V}$ attributed the dodecamolybdate cluster and a process reduction attributed to lantharide ions. These compounds exhibit remarkable yields for the degradation of Naphthol Blue Black solutions that has been chosen as a model of organic dyes. In fact, the removal exceeds, respectivdy, $60 \%$ and $80 \%$ for compounds (1) and (2) after 2 hours of reaction 